\title{
Isoquinolone alkaloids mitigate microscopic digestive tract lesions induced by sub-acute ruminal acidosis (SARA) in feedlot cattle
}

\section{Alcaloides isoquinolínicos atenuam lesões microscópicas digestivas induzidas por acidose ruminal subaguda em bovinos confinados}

\author{
Adrien Wilhelm Dilger Sanches ${ }^{1 *}$; Fabiano Montiani-Ferreira²; Elizabeth Santin²; \\ Mikael Neumann ${ }^{3}$; Angela Maria Reck ${ }^{4}$; Heloisa Godoi Bertagnon ${ }^{5}$; \\ José Ricardo Pachaly ${ }^{6}$
}

\section{Highlights:}

Feedlot cattle under a high-grain diet and supplemented with isoquinolone alkaloids had their gastro intestinal lesions evaluated.

The rumen and reticulum of the treated group showed a significant reduction in the epithelial hydropic degeneration scores and lamina propria inflammation All non-keratinized tissues, except for ileum, had a significant decrease in the total counting of inflammatory cells.

\begin{abstract}
Feedlot cattle is submitted to a diet rich in energy and reduced in fibres that induces the sub-acute ruminal acidosis (SARA) with its lesions and clinical signs. Recent studies have demonstrated some amelioration of this condition by the use of isoquinolone alkaloids found in Macleaya cordata (Papaveraceae) such as Sanguinarine and Chelerythrine. These compounds have demonstrated antimicrobial, antiinflammatory and immune-modulatory effects in both humans and animals The aim on this study, using histopathology and a score system, was to evaluate the differences between a non-treated and a treated group feed with these alkaloids, present in trade preparation Sangrovit-RS ${ }^{\circledR}$ as a source of sanguinarine (SG), chelerythrine $(\mathrm{CH})$ and protropine $(\mathrm{PA})$ standardized to $0.15 \% \mathrm{w} / \mathrm{w} \mathrm{SG}$, using feedlot cattle under a high-grain diet as an inflammatory model for gastrointestinal system. The samples of forestomachs were evaluated and graded using scores ranging from zero ( 0 ) to three (3) obtained at light-microscopic fields of 400X. Parameters such as inflammation, hydropic degeneration, hyperkeratosis, and vesicle formation were accessed in the different layers of the tissues, considering the severity and dispersion of the microscopic lesions. The soft tissues such as the abomasum, small intestine, cecum and colon had their total amount of inflammatory cells counted at light-microscopic fields of 200X. The rumen of the SG-CH-PRO-treated group showed a significant reduction in the epithelial hydropic degeneration scores $(\mathrm{p} \leq 0.001)$ and lamina propria inflammation $(\mathrm{p} \leq 0.001)$. The reticulum had a similar reduction in
\end{abstract}

\footnotetext{
' Discente do Curso de Doutorado do Programa de Pós-Graduação em Ciência Animal, Universidade Federal do Paraná, UFPR, Curitiba, PR, Brasil. E-mail: morphovet1972@gmail.com

2 Profs. Drs., Departamento de Medicina Veterinária, UFPR, Curitiba, PR, Brasil. E-mail: montiani@ufpr.br; besantin@hotmail. com

3 Prof. Dr., Universidade Estadual do Centro Oeste, UNICENTRO, Guarapuava, PR, Brasil. E-mail neumann.mikael@hotmail. com

4 Discente do Curso de Mestrado do Programa de Pós-Graduação em Ciência Animal, UNICENTRO, Guarapuava, PR, Brasil. E-mail: angelareck@hotmail.com

5 Prof ${ }^{a}$ Dra $^{\mathrm{a}}$, Programa de Pós-Graduação em Ciência Animal, UNICENTRO, Guarapuava, PR, Brasil. E-mail: hbertagnon@ hotmail.com

6 Prof, Dr., Programa de Pós-Graduação em Ciência Animal da Universidade Paranaense, UNIPAR, Umuarama, PR, Brasil. E-mail: pachaly@uol.com

* Author for correspondence
} 
scores of epithelial $(\mathrm{p} \leq 0.002)$ and stratum corneum hydropic degeneration $(\mathrm{p} \leq 0.001)$, hyperkeratosis $(\mathrm{p} \leq 0.002)$ and inflammation in lamina propria $(\mathrm{p} \leq 0.001)$ and epithelium $(\mathrm{p} \leq 0.002)$. The omasum had no significant differences. All non-keratinized tissues, except for ileum, had a significant decrease ( $\mathrm{p} \leq$ 0.001 ) in the total counting of inflammatory cells. In this trial, the feedlot cattle feed with high grain diet and treated with isoquinolone alkaloids expressed lesions that indicate ameliorations and worsening's. Ameliorating effects of the alkaloids were better demonstrated in tissues with reduced or no corneal layer in the mucosa and in the absence of a lipopolysaccharides rich acidic environment reinforcing the notion of the topic action, the dependence of the media $\mathrm{pH}$ and the time of exposure modulating the pharmacological mechanisms of these alkaloids. The observed cytolytic (oncolysis) effect in epithelial forestomachs cells under low $\mathrm{pH}$ values, worsening the osmotic status, should be considered before clinical applications.

Key words: Chelerythrine $\mathrm{Na}+$. K+- ATPase pump. Ruminitis. Sanguinarine.

\section{Resumo}

As dietas para bovinos confinados possuem alta quantidade de alimentos energéticos com menor quantidade de alimentos volumosos (fibras), favorecendo a indução de acidose ruminal subaguda com formação de lesões gastrointestinais e sintomas clínicos deletérios. Recentes trabalhos têm demonstrado alguma amenização desta condição pelo uso de alcaloides isoquinolínicos encontrados na Macleaya cordata (Papaveraceae) tais como a sanguinarina e a cheleretrina, os quais tem demonstrado efeitos anti-inflamatórios, antimicrobianos e imuno modulatórios em humanos e animais. O objetivo deste estudo foi, através da histopatologia e de um sistema de escores, avaliar as diferenças entre um grupo não tratado e um grupo tratado com alcaloides isoquinolínicos, presentes na formulação Sangrovit $\mathrm{RS}^{\circledR}$ como fonte de sanguinarina $(\mathrm{SG})$, chelerethrina $(\mathrm{CH})$ and protropina $(\mathrm{PA})$ padronizadas em $0,15 \% \mathrm{w} / \mathrm{w}$ $\mathrm{SG}$, usando bovinos em confinamento recebendo uma dieta rica em grãos como modelo inflamatório para o sistema gastrointestinal. Amostras dos pré-estômagos foram avaliadas por escores variando de zero a três, obtidos por microscopia de luz em diferentes campos em aumentos de 400X. Inflamação, degeneração hidrópica, hiperqueratose e formação de vesículas foram avaliadas nas diferentes camadas dos pré-estômagos tendo em vista a intensidade e a extensão das lesões. Tecidos não queratinizados como abomaso e intestino delgado, ceco e cólon tiveram seu total de células inflamatórias contadas por microscopia de luz em diferentes campos com aumentos de 200X. No rumem do grupo tratado houve uma redução significante no número de campos contendo degeneração hidrópica epitelial $(\mathrm{p} \leq$ $0,001)$ e inflamação de lâmina própria $(\mathrm{p} \leq 0,001)$. O retículo teve uma redução similar nos escores scores de degeneração hidrópica epitelial $(\mathrm{p} \leq 0.002)$, degeneração hidrópica no estrato córneo ( $\mathrm{p} \leq 0.001)$, hiperqueratose $(\mathrm{p} \leq 0.002)$ e inflamação na lamina própria $(\mathrm{p} \leq 0.001)$ e inflamação epitelial $(p \leq 0.002)$. Não foram encontradas diferenças significantes no omaso. Todos os tecidos não queratinizados, exceto pelo íleo, tiveram uma redução significativa $(p \leq 0.001)$ no total de células inflamatórias. Neste experimento, bovinos em confinamento recebendo dieta rica em grãos e tratados com alcaloides isoquinolínicos tiveram lesões que tiveram melhoras e pioras. Os efeitos de melhora foram melhor demonstrados em tecidos sem camada córnea e na ausência de um meio ácido rico em lipopolisacarídeos, reforçando a noção da ação tópica, da dependência do $\mathrm{pH}$ do meio e do tempo de exposição modulando os mecanismos farmacológicos destes alcalóides. O efeito citolítico (oncólise) sobre células epiteliais de pré-estômagos em baixos valores de $\mathrm{pH}$, piorando o estado osmótico das células, deveria ser considerado antes das aplicações clínicas.

Palavras-chave: Bomba Na+. K+- ATPase. Queleritrina. Rumenitis. Sanguinarina. 


\section{Introduction}

The demand in the global meat market has induced a dietary change in feedlot cattle that replaced the traditional diets rich in fibers $(70 \%$ forage and $30 \%$ grain) for one with more energy containing higher percentage of grains (Millen \& Arrigoni, 2013). The direct side effect of these diets is the lowering of the $\mathrm{pH}$ of the forestomachs contents leading to clinical ruminal acidosis in the acute and/or the chronic forms. The non-lethal, sub-clinical, chronic form is also named sub-acute ruminal acidosis (SARA).

These diets also have a reduced proportion of fiber reducing ruminal motility and favor VFAs (Volatile Fatty Acids) to pool in the rumen, helping to induce SARA, alongside lactic acid production (Plaizier, Khafipour, Li, Gozho, \& Krause, 2012). SARA results in negative effects on the animals' performance and health, as the microbiota and low $\mathrm{pH}$ changes even affects the ruminal wall integrity.

Associated with gram-negative bacterial lysis and the releasing of endotoxins known as lipopolysaccharides (LPS), the start of an inflammatory cascade occurs and this may lead ruminal hypotony/atony with hydrorumen and a typical parakeratosis-rumenitis liver abscess complex, associated with a plethora of systemic manifestations such as diarrhea and dehydration, liver abscesses, infections of the lung, the heart, and/ or the kidney, and laminitis, as well as neurologic symptoms due to both cerebrocortical necrosis and the direct effect of D-lactate on neurons. (Hernández, Benedito, Abuelo, \& Castillo, 2014). The consequence of these lesions is a reduced performance observed by the feed intake and the feed conversion ratio parameters (Sato, 2015).

To reduce the side effects of SARA ionophore antibiotics and "natural products" have been in use. Ionophores, in ruminants feeding with highcarbohydrate diets, stimulates the absorption of VFAs and $\mathrm{H}+$ from the rumen thus controlling the fall of the ruminal $\mathrm{pH}$ (Costa et al., 2008).
"Natural products" started to be recognized as important source of therapeutically effective substances in food animal production in recent years. These phytogenic feed additives are commonly defined as plant-derived compounds incorporated into feed to improve the productivity of livestock (Windisch, Schedle, Plitzner, \& Kroismayr, 2008). A number of plant compound used in livestock are also used in traditional medicine.

One of these plants, the Macleaya cordata (Willd.) R.Br. (Papaveraceae) has compounds classified as benzo[c]phenanthridine alkaloids (QBAs), represented mainly by the sanguinarine (SG) and chelerythrine $(\mathrm{CH})$. This group also includes protopine (PRO), allocryptopine (ALL), dihydrosanguinarine (DHSA), dihydrochelerythrine (DHCHE), oxysanguinarine (OSA) and berberine (BER) (Hu, Xu, Feng, \& Guang-Jin, 1979; XuBiao, Chen, \& Yao, 2006). SG and $\mathrm{CH}$ are known to have antimicrobial, anti-inflammatory and immune-modulatory effects in humans (e.g. dental health) and animals (Lenfeld et al., 1981; Newton, Lau, Gurcha, Besra, \& Wright, 2002; Jankowski et al., 2009). The best-known property of SG is an antibacterial effect, already described in the 1950s (Johnson, Jonhson, \& Poe, 1952) and confirmed in vitro and in vivo in later researches (Walker, 1990; Herrera-Mata, Rosas-Romero, \& Crescente, 2002; Mahody, Pendland, Stoia, \& Chadwhick, 2003).

The aim on this study was to evaluate the histopathological changes in tissue samples from the digestive tract of feedlot cattle receiving a highgrain diet as an inflammatory model, and compare results between the group treated with isoquinolone alkaloids (SG, HC and PRO) and a control group.

\section{Materials and Methods}

\section{Location and facilities}

The research was conducted and executed by the Programa de Pós Graduação em Ciência Animal da Universidade Estadual do Centro Oeste - 
UNICENTRO (Animal Science Graduate Program of the UNICENTRO) in the state of Paraná, Southern Brazil. The study was approved by the animal welfare committee of the UNICENTRO (COMITE DE ÉTICA EM USO DE ANIMAIS, CEUA / UNICENTRO) by the protocol $021 / 2015$ released in $11 / 09 / 2015$. The pens and the animals were housed in the UNICENTRO's Animal Production Center, in the city of Guarapuava, State of Paraná,

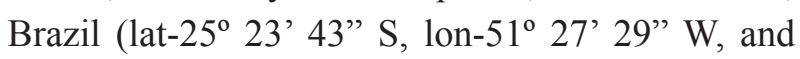
alt-1098 m). The slaughterhouse was located in the same city.

\section{Animals}

Sixteen Angus half-breed non-neutered bulls fed with a high grain diet were orally supplemented with trade preparation. The bulls were eleven months in age, initially weighting $350 \mathrm{~kg}$ in average being allocated in two per pen. The pens were supplied with automatic waterers.

\section{Study design, nutrition and management}

The study was entirely randomized. One group of eight animals served as the control and received only a high grain diet and the other group of eight animals received the same diet plus $4 \mathrm{~g} /$ day of trade preparation containing isoquinolone alkaloids (SG, $\mathrm{CH}$ and PRO). The research lasted 116 days and was preceded by two weeks of diet adaptation.

The adaptation protocol to the high energy diet consisted in the first four days of $1.2 \%$ of BW concentrate mixture (protein-vitamin-mineral nucleus): $15 \%+$ whole corn grain: $85 \%$ and corn silage (ad libitum); as of the fifth day it was provided $1.6 \%$ of $\mathrm{BW}$ of the concentrate mixture and corn silage (ad libitum); in the tenth day it was provided $1.8 \%$ of BW and it was started a reduction of corn silage supply of $25 \%$ in relation to the previous day until the corn silage, thus turning available only the concentrate mixture in the trough as "ad libitum" with daily supply adjustments. On Day 0, the animals received a diet composed of concentrated mixture and corn silage. The diet was balanced in $80 \%$ of whole corn grain, $20 \%$ of protein-vitaminmineral.

Diets were provided "ad-libitum twice" a day, at 7:00 a.m. and 5:30 p.m. The RTM was prepared at the Agricultural Cooperative commercial feed plant located in the Entre Rios district (Guarapuava, PR, Brazil). The following food items were used to prepare the pelleted protein concentrate: soybean meal, wheat bran, malt radicle, calcitic limestone, dicalcium phosphate, livestock urea, vitamin and mineral premix, common salt, sodium monensin $\left(75 \mathrm{mg} / \mathrm{kg}^{-1}\right)$ and virginiamicin $\left(75 \mathrm{mg} / \mathrm{kg}^{-1}\right)$.

This way, the diet protein nucleus presented the percentage mean contents of: $90.22 \% \mathrm{MS} ; 42.23 \%$ PB; 2.59\% EE; 24.61\% FDN; 12.28\% FDA; $16.31 \% \mathrm{MM} ; 2.77 \% \mathrm{Ca} ; 1.11 \% \mathrm{P}$ and $1.57 \% \mathrm{~K}$, based on the total dry material. The composition the ration included soybean meal, wheat meal, malt sprouts, lime, dicalcium phosphate, agricultural urea, vitamin-mineral premix and sodium chloride.

\section{The alkaloid composition}

The trade preparation Sangrovit-RS ${ }^{\circledR}$ was used as a source of $\mathrm{SG}, \mathrm{CH}$ and PRO. The treated group received corn kernel (10 g per animal) with Sangrovit-RS ${ }^{\circledR}$, poured over the mixed feed (RTM), in the moment of the feeding to assure the ingestion of the product. It resulted in approximately in $6 \mathrm{mg}$ of SG a day. Sangrovit-RS ${ }^{\circledR}$ is made from Macleaya cordata by the Phytobiotics Feed Additives GmbH (Eltville, Germany). It is obtained from intact aerial parts of the plant resulting in a fraction of quaternary benzo[c]phenanthridine alkaloids (QBAs), mainly SG, CH and PRO being standardized to $0.15 \% \mathrm{w} / \mathrm{w}$ SG (Zdarilova, Vostálová, Vrublova, \& Klejdus, 2008; Kosina et al., 2010). 


\section{Ruminal fluid gathering and $\mathrm{pH}$ analysis}

The ruminal fluid was obtained through ruminocentesis. The samples were gathered the day before the introduction of the adaptation diet, after the diet adaptation at day 0 and at the day of the slaughter. Four hours of fasting preceded the centesis of the rumen posterior ventral sac using a catheter $14 \mathrm{G}$ coupled to a $20 \mathrm{ml}$ syringe. The insertion point was located between 12 to $15 \mathrm{~cm}$ from the costochondral junction of the last rib by the level of the patellar crest. For the procedure the animal was restrained in a squeeze chute, the local skin was previously shaved and disinfected with a $10 \%$ povidone-iodine and $70 \%$ isopropyl alcohol solution. No topic anaesthetic was used (Tajik, Nadalian, Raoofi, Mohammad, \& Bahonar, 2009). Right after, the $\mathrm{pH}$ was measured in a Kasvi ${ }^{\circledR}$, K39-0014PA (São Paulo, Brazil) digital ph meter.

\section{Sample gathering of tissues and process}

During slaughtering, the removed gastrointestinal tissues were grossly evaluated and photographed when distinct lesions were seen.

All sixteen forestomachs, abomasa, duodena, jejuna, ilea, ceca and colons had their mucosae exposed, evaluated and had their samples collected (5-10 cm in length) for fixation in $10 \%$ buffered formalin. Each larger tissue sample resulted in three trimmed samples per glass slide.

Rumen was sampled in the cranial, middle and caudal portions of the ventral sac and in the middle portion of the dorsal sac. Reticulum, omasum, abomasum, duodenum, jejunum, ileum, cecum and colon were sampled in their middle regions. Trimming of each large sample resulted in three minor samples per slide, totalizing 192 smaller samples of rumem, 48 of reticulum, 48 of omasum, 48 of abomasum, 48 of duodenum, 48 jejunum, 48 ileum, 48 cecum and 48 colon. They were routinely processed for confection of histological paraffin blocks with subsequent staining by Hematoxylin and Eosin.

\section{The scoring system}

The scoring of keratinized tissues was accomplished by checking eight light-microscopy fields of 400x augmentation, per smaller sample. Each field had one papilla. In the 16 animals a total of 1536 ruminal papillae (96/animal), 384 reticulum papillae (24/animal) and 384 omasum papillae (24/ animal) were graded.

The scoring model was based on the ISI ${ }^{\circledR}$ method (Kraieski, Hayashi, Sanches, Almeida, \& Santin, 2017; Belote et al., 2018). In this protocol the determination of the scores considers the extension, the intensity and the observed frequency of the histopathological change (parameter) in 400x augmentation microscopic fields. The following scores were used: Score 0 (absence of lesions or presence of minor ones), Score 1 (25\% of the total area of the tissue showing lesions), Score 2 (25 to $50 \%$ of the area showing lesions), and Score 3 (more than $50 \%$ of the area examined showing lesions).

The ruminal, reticular and omasal parameters (per papilla) compared were: inflammation in lamina propria, stratum corneum (pustules), epithelium (micro abscesses), hydropic degeneration in the epithelial cells, hydropic degeneration in the stratum corneum, hyperkeratosis in the stratum corneum, vesicle formation in the epithelium and vesicle formation in the stratum corneum. For the omasum, the parameter edema in the lamina propria was added.

The interpretation of the forestomachs data considered the total number of $400 \mathrm{x}$ augmentation microscopic fields, each field with one papilla, containing the score 0 against the total number of fields containing any degree $(1+2+3)$ of the chosen lesion (parameter).

Each smaller sample of soft tissue such as abomasum, small intestine, cecum and colon had five 200X augmentation light-microscopic fields per small sample photographed. In the 16 animals a total of 240 abomasa (15/animal), 240 duodena 
(15/animal), 240 jejuna (15/animal), 240 ileal (15/animal), 240 ceca (15/animal) and 240 colon (15/animal) 200X augmentation fields, chosen randomly, had their inflammatory cells (all types) marked and counted. The software Windows Photo Paint ${ }^{\circledR}$ was used to manual marking and counting of macrophages, neutrophils, plasma cells and lymphocytes found in the lamina propria of the villi and the crypts. The selection of the cells was made by an experienced veterinary pathologist.

\section{Statistical analysis}

The Shapiro-Wilk test demonstrated that the data was not normally distributed. A Mann-Whitney U test was used for data comparisons of the SG-CHPRO-treated versus non-treated group regarding the 0-3 histopathology scores and an unpaired t-test was used to compare the total number of inflammatory cells between the two groups, using StatView ${ }^{\circledR}$ 5.0.1 (SAS Institute, Cary NC).

\section{Results and Discussion}

Ph results

Mean ruminal $\mathrm{pH}$ values, obtained the day before the inclusion of the diet, were 7.0 in both groups. In the day after the inclusion of the diet, both groups had $\mathrm{pH}$ 6.0. In the day of the slaughtered, the control group had $\mathrm{pH} 5.5$ and the SG group had $\mathrm{pH}$ 6.0. This study obtained a $\mathrm{pH}$ of 5.5 at the slaughterhouse, against an average $\mathrm{pH}$ of 7.0 before the inclusion of the diet. This value meets those described for SARA that considers the fall of ruminal $\mathrm{pH}$ at or below 5.5 some hours after concentrate feeding (Oetzel, 2000) and values between 5.6 and 5.7 as a transition towards SARA by some authors (Morgante, Stelletta, Berzaghi, Gianesella, \& Andrighetto, 2007).

\section{Gross lesions}

Rumen and reticulum of all animals in both groups, revealed the papillae rougher than normal by touch at the gross evaluation. This roughness was later confirmed in histopathological examination as being caused by hyperkeratosis in the papillae. The presence of hyperkeratosis agrees with the dally feeding of the animals with a non-lethal high grain diet and the description of the literature (Hernández et al., 2014). Only the ruminal mucosa also had some multifocal areas characterized by fused and thicker papillae (Figure 1A) and the presence of the large amount of acidic content when compared to reticulum, can explain this findings. Additionally the absence of erosions/ulcers, sites of hemorrhage or scars were not observed and aggress with the proposition of experimentally induced SARA. Redness in the abomasum mucosa was seen in half (4) of the animals of each group (Figure 1B), being characterized later in histopathology as being caused by inflammation (abomasitis). It was probably clinked to the still acidic content from the fore stomachs ( $\mathrm{pH} 5.5$ or 6.0 ). 


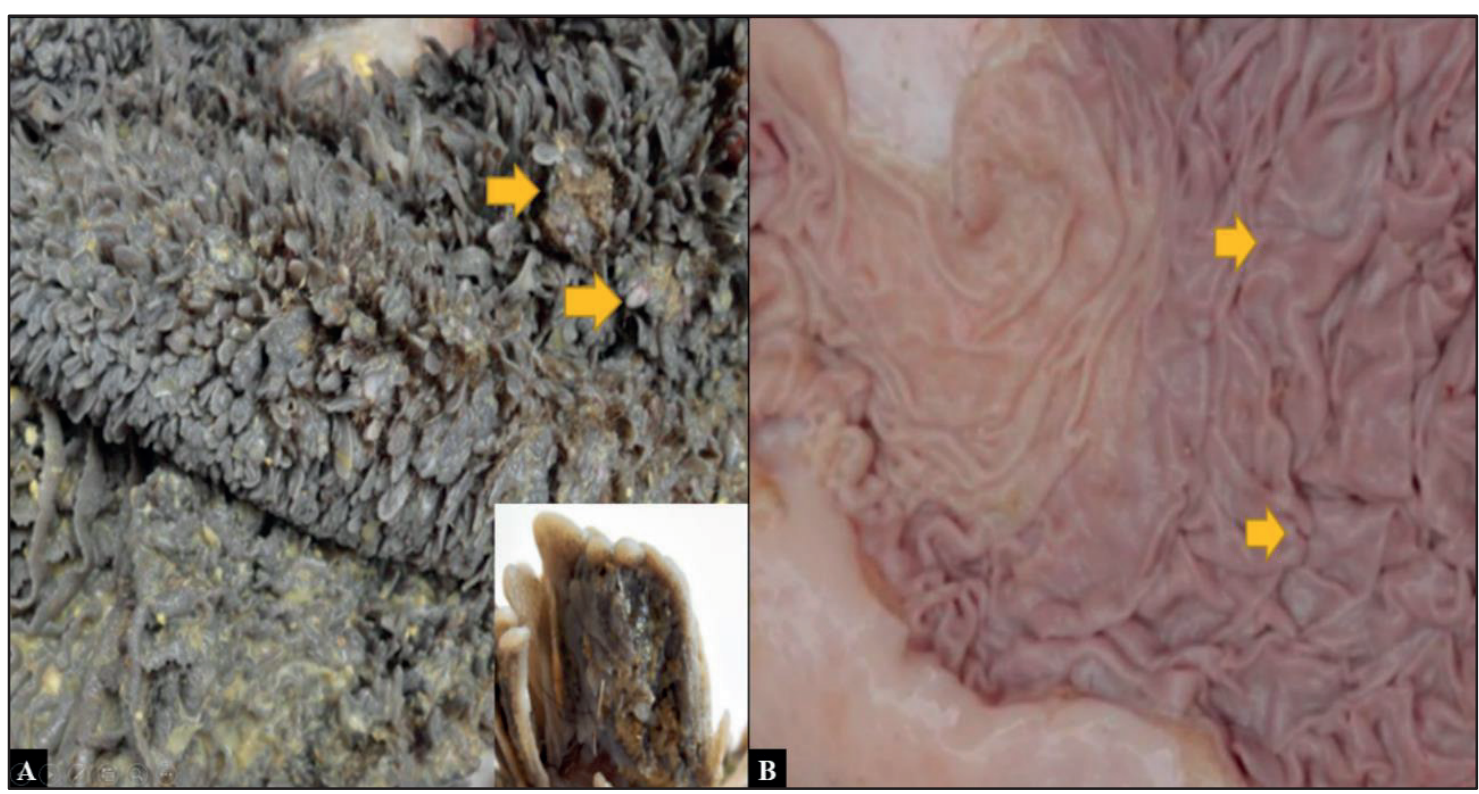

Figure 1. Gross lesions of SARA. A - Rumen with multifocal areas of severe hyperkeratosis (arrows) composed by fused and thicker papillae (window) in the mucosa. B - Abomasum with hyperemia (arrows).

\section{General histopathology}

The microscopic evaluation of the rumen, reticulum and omasum revealed that most papillae had at least some amount of the parameters evaluated. Just a minor number of papillae were normal (Figure 2A). In the rumen, scattered neutrophils and multifocal micro abscesses were present in the stratum corneum (Figure 2B). In the lamina propria a diffuse chronic inflammatory infiltrate composed by lymphocytes and macrophages, with a small amounts of neutrophils was observed (Figure 2C). Additionally, hyperkeratosis (Figure 2D), epithelial inflammation, epithelial hydropic degeneration (Figure 2E), corneal pustules, corneal vesicles (Figure 2F) were also observed. Reticulum had normal papilla (Figure 3A) and similarly lesioned ones except for the absence of the corneal pustules/ abscesses.
The presence of ruminal neutrophils in an experimental chronic situation could be explained by the everyday feeding with the high grain diet creating new episodes of reduced $\mathrm{pH}$ resulting in acute inflammatory episodes. The reticulum faster transit and less amount of acidic content can explain the absence of the corneal pustules/abscesses.

Lesions in the abomasum comprised inflammation (abomasitis) expressed by multifocal or extensive focal areas of inflammatory cells located mainly in the lamina propria of the gastric glands (Figure 3B). In some areas of the mucosa, a minor fibrinous exudate was be seen in the surface of the mucosa 


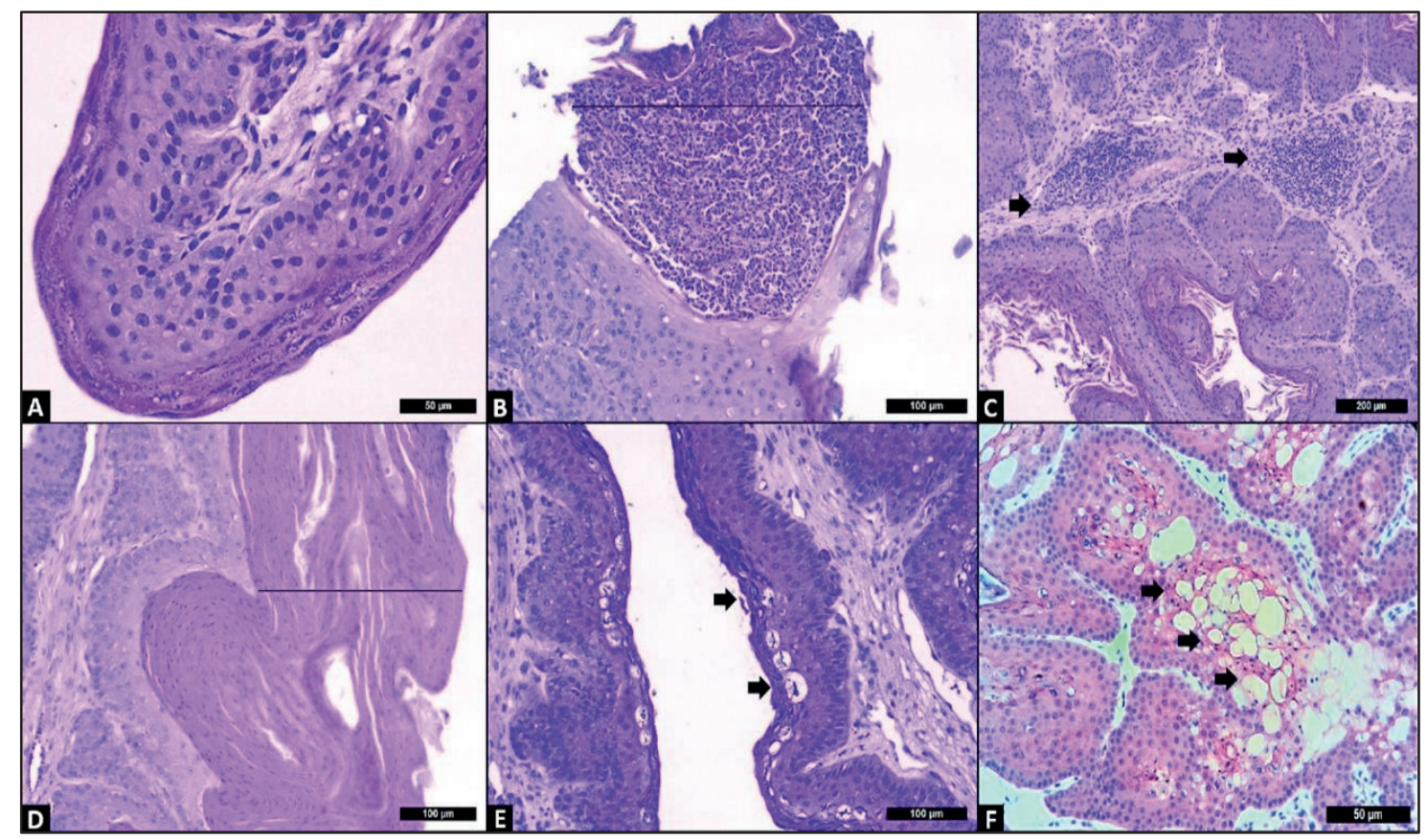

Figure 2. Forestomachs microscopic lesions in SARA. Normal ruminal papila, 400X (A); Ruminal corneal pustule, score III, 200X* (B); Ruminitis score II, 100X* (C); Ruminal corneal hyperkeratosis score III, 200X* (D); Ruminal epithelial hydropic degeneration, 200X* (E); Ruminal epithelium vesicles, $400 X^{*}(\mathrm{~F})$; All samples stained with Hematoxylin and Eosin. *Different magnifications were chosen to better demonstrate the lesions.

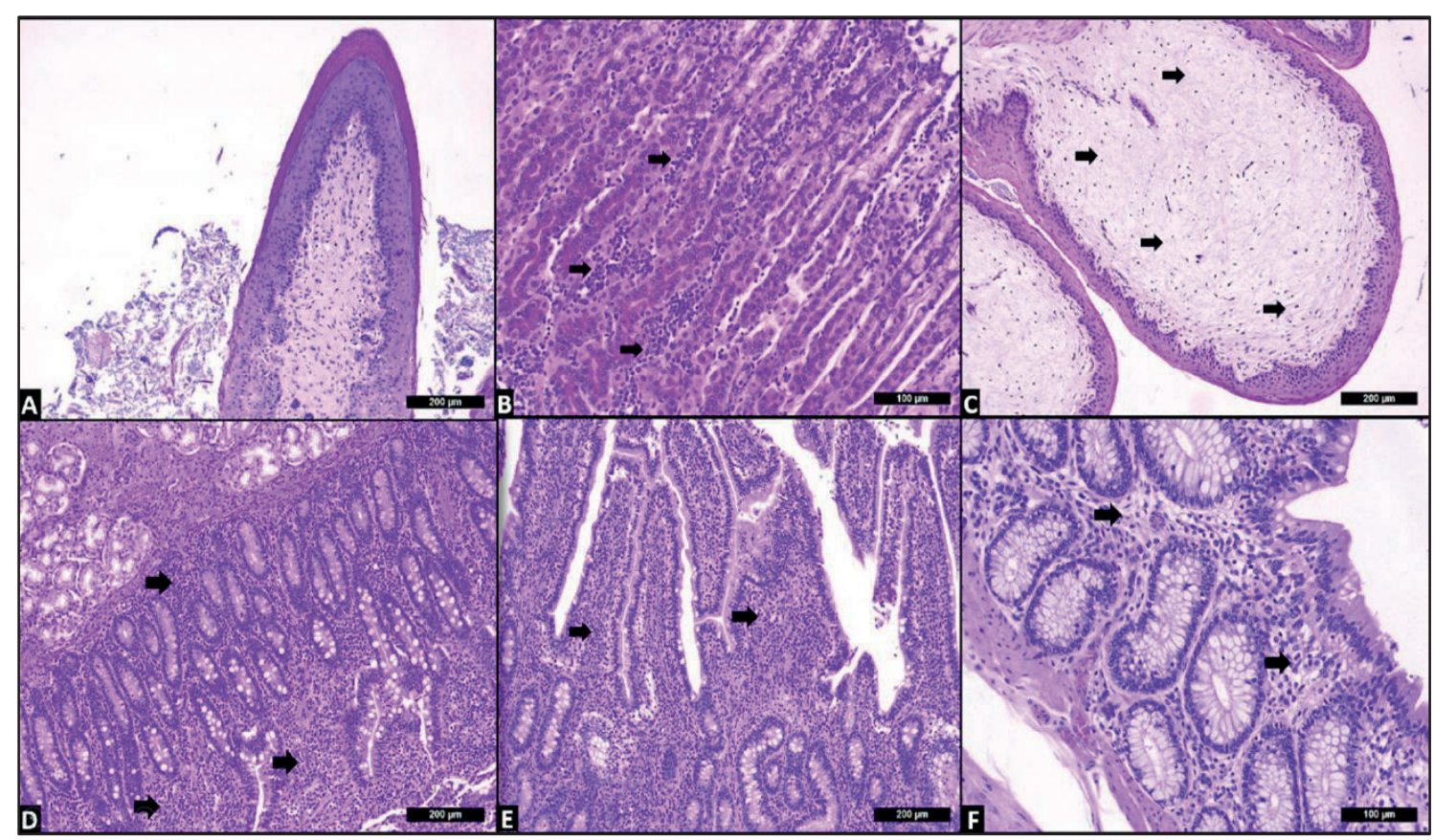

Figure 3. Reticulum, omasum and soft tissues microscopic lesions in SARA. Normal reticulum papilla, 100X* (A); Abomasum with inflammatory cells (abomasitis), 200X* (B); Omasum with enlarged lamina propria score III, (edema), 100X* (C); Duodenum with inflammatory cells (enteritis), in lamina propria, $100 X^{*}(\mathrm{D})$; Ileum with inflammatory cells in lamina propria, 100X*(E); Colon with inflammatory cells (enteritis) in lamina propria, 200X* (F). All samples stained with Hematoxylin and Eosin. *Different magnifications were chosen to better demonstrate the lesions. 
The main change in the omasum was a chronic inflammatory infiltrate, located mainly in the lamina propria, composed by lymphocytes and less amount of macrophages with some amount of neutrophils. The intensity of the inflammation was less severe than that observed in the forestomachs. The lamina propria was larger than the normal in many of the papillae being characterized by a fainter dye in the absence of congestion, hemorrhage or inflammatory cells characterizing edema. (Figure 3C).

The intestinal predominant lesion was a diffuse chronic inflammation (enteritis) located mainly in the lamina propria of the duodenum (Figure 3D), jejunum, ileum (Figure 3E), cecum and colon (Figure 3F). Some inflammatory cells were observed over the epithelium. The thickness of the lamina propria was increased due the infiltration of the inflammatory cells and these were comprised mostly by lymphocytes followed by an smaller amount of macrophages and neutrophils. The presence of neutrophils in a chronic situation could be explained again by the everyday feeding with the high grain diet creating new episodes of reduced $\mathrm{pH}$ resulting in acute inflammatory episodes.

\section{Statistical histopathology}

In the statistical analysis, the rumen of the treated animals had significantly $(\mathrm{p} \leq 0.001)$ reduced number of 400x augmentation fields with score 0 (absence of lesions) for inflammation in the lamina propria and significantly less fields with higher scores $(1+2+3)$ of epithelial hydropic degeneration $(p \leq 0.001)$. In the non-treated group, significant less fields $(p \leq 0.017)$ with higher scores for stratum corneum vesicles was observed (Table 1). The reduction in the number of fields with 0 score for lamina propria inflammation describe an indirect pro-inflammatory effect accompanied by a raise in the number of stratum corneum vesicles in low $\mathrm{pH}$. The raised amount of vesicles would allow more bacteria and lipopolysaccharides to enter the mucosa stimulating the inflammation in the epithelium and lamina propria. These results demonstrate the reduction of the topic effects of these alkaloids (Kosina et al., 2010) on a strongly keratinized mucosa in low $\mathrm{pH}$. Deeper, in the epithelium, a reduction in the amount of hydropic cells was observed and seems to illustrate some cell membrane stabilizing effect of the alkaloids. One possible mechanism for this control could be the fact that SG raise the production/activation of Cyclic Adenosine Monophosphate (cAMP) by this increasing cell surface expression of functional $\mathrm{Na}, \mathrm{K}$-ATPase units, $\mathrm{Na}$ is pumped out of the cell, reducing the cell oedema of the epithelial cells under the stratum corneum (Gonin et al., 2001).

Table 1

Ruminal scores, total number of fields and p-values

\begin{tabular}{|c|c|c|c|c|}
\hline & Scores & Non-treated & Treated & p-value \\
\hline Inflammation lamina propria & 0 & 510 & 369 & $\mathrm{p} \leq 0.001$ \\
\hline Stratum corneum vesicles* & $1+2+3$ & 3 & 15 & $\mathrm{p} \leq 0.017$ \\
\hline Epithelial hydropic degeneration & $1+2+3$ & 560 & 435 & $\mathrm{p} \leq 0.001$ \\
\hline
\end{tabular}

*The non-treated group demonstrated significantly less lesions for this parameter.

The biochemical effects of these alkaloids also depends on $\mathrm{pH}$ (Slaninova, Taborska, Bochorakova, \& Slanina, 2001). In physiological pH (7.4), the alkaloids are found outside the cell in a pro-drug pseudo base form $\left(\mathrm{OH}^{-}\right)$.They penetrate the cell membrane in the form of nonpolar pseudobase and 
once inside the cell the molecules exchange the $\mathrm{OH}^{-}$ to $\mathrm{H}^{+}$and the cationic form starts to act raising the cAMP helping to control the osmotic status of the cells. Another described effect of these alkaloids in the direct inhibition of the Na, K-ATPase pump depending on the time of exposure and concentration (Straub \& Carver, 1975; Pitts \& Meyerson, 1981; Lauf, et al., 2013). The raised amount of stratum corneum vesicles in the acidic media would be the direct consequence on the inhibition of the $\mathrm{Na}$, K-ATPase pump modulated by time concentration and low $\mathrm{pH}$. Acidic contents in forestomachs are known to induce hydropic degeneration with subsequent formation of vesicles and pustules in the mucosa. Once the membrane $\mathrm{Na}+, \mathrm{K}+$-ATPase pump in the corneum layer is damaged by the low $\mathrm{pH}$ the inhibitory action of the alkaloids on the pumps would finally break the osmotic equilibrium of the cells leading to their edema and/or destruction (Armstrong, 2003).The cytolytic effect of these alkaloids should be considered as a side effect in forestomachs acidic conditions.
Reticulum inflammatory parameters behaved the same way as the ruminal lamina propria inflammation, with reductions in score 0 . They were also associated with worsening (less scores 0) in epithelial hydropic degeneration, epithelial vesicles and stratum corneum vesicle formation. The data again describe an indirect pro-inflammatory effect accompanied by probable instability in the epithelial cell membranes due a reduced $\mathrm{pH}$ environment added to the effects of the alkaloids. The raised amount of ruptured vesicles would allow more bacteria and lipopolysaccharides to enter the mucosa stimulating the inflammation in the epithelium and lamina propria. Ameliorative effects (less scores $1+2+3$ ) were seen on epithelial hydropic degeneration, stratum corneum hyperkeratosis and stratum corneum hydropic degeneration (Table 2). These seemed to depend on the previous activation of the $\mathrm{Na}+, \mathrm{K}+$-ATPase pump $(\mathrm{Na}+$ previous entrance) since the scores 0 were reduced in the treated group, except for the hyperkeratosis.

Table 2

Reticulum scores, total number of fields and p-values

\begin{tabular}{ccccc}
\hline & Scores & Non treated & Treated & $\mathrm{p}$-value \\
\hline Inflammation lamina propria & 0 & 145 & 85 & $\mathrm{p} \leq 0.001$ \\
\hline Epithelial hydropic degeneration & 0 & 23 & 8 & $\mathrm{p} \leq 0.025$ \\
\hline Epithelial hydropic degeneration & $1+2+3$ & 168 & 112 & $\mathrm{p} \leq 0.006$ \\
\hline Stratum corneum hyperkeratosis & $1+2+3$ & 181 & 116 & $\mathrm{p} \leq 0.002$ \\
\hline Stratum corneum inflammation & 0 & 189 & 120 & $\mathrm{p} \leq 0.001$ \\
\hline Epithelial Inflammation & 0 & 184 & 119 & $\mathrm{p} \leq 0.002$ \\
\hline Epithelial vesicles & 0 & 190 & $\mathrm{p} \leq 0.001$ \\
\hline Stratum corneum vesicle formation & 0 & 189 & 119 & $\mathrm{p} \leq 0.001$ \\
\hline Stratum corneum hydropic degeneration & $1+2+3$ & 93 & 56 & $\mathrm{p} \leq 0.013$ \\
\hline
\end{tabular}

The more favorable reticulum results could also be explained by the less amount and reduced permanence of the acidic content in this organ mucosa mainly expressed in the outer layer of the mucosa. The reduction of the hyperkeratosis could explain the higher number of the stratum corneum inflammation and stratum corneum vesicle formation since hyperkeratosis is a form of physical epithelial defense. Rumen and reticulum results for the hydropic cells and hyperkeratosis are in 
accordance with those of obtained in ewes (EstradaÂngulo et al., 2016). Additionally, the reduction observed in the ruminal and reticulum hydropic degeneration would allow more absorption of acids by the papilla and thus raise the $\mathrm{pH}$ from 5.5 to 6.0. Since the length of the papilla increases when cattle are feeding high grain diets (Dirksen, Liebich, \& Mayer, 1985), this slight improvement in $\mathrm{pH}$ of the mucosa health could ameliorate the ruminal conditions.

None of the omasum parameters had a statistical significance but just this organ had evident edema in the lamina propria. Considering the physiology of this organ, the dehydration of the luminal content would certainly concentrate the pro-inflammatory E coli endotoxins-LPS (Hernández et al., 2014) amount, erasing any possible effect of alkaloids in the histopathology.

The apparent maximum number of inflammatory cells in the samples of the abomasum was statistically reduced in the treated animals. The same results were found for the duodenum, jejunum, cecum and colon. The absence of a keratinized mucosa and a more acid environment certainly allowed the antiinflammatory effect of the alkaloids to be expressed (Table3).

Table 3

Non-keratinized tissue amount (number) of inflammatory cells and p-values

\begin{tabular}{|c|c|c|c|}
\hline & Non treated & Treated & p-value \\
\hline Abomasum & 18392 & 17595 & $\mathrm{p} \leq 0.006$ \\
\hline Duodenum & 44975 & 28739 & $\mathrm{p} \leq 0.001$ \\
\hline Jejunum & 45029 & 39088 & $\mathrm{p} \leq 0.001$ \\
\hline Ileum* & 28175 & 34240 & $\mathrm{p} \leq 0.001$ \\
\hline Cecum & 45675 & 43619 & $\mathrm{p} \leq 0.001$ \\
\hline Colon & 43588 & 32926 & $\mathrm{p} \leq 0.001$ \\
\hline
\end{tabular}

*The non-treated group demonstrated significantly less lesions for this parameter only.

The SG and $\mathrm{CH}$ are known to have antimicrobial, anti-inflammatory and immune-modulatory effects in humans and farm animals (Lenfeld et al., 1981; Newton et al., 2002; Jankowski et al., 2009). In rats treated with SG, HC and PRO (500 $\mathrm{ppm}$ of Sangrovit ${ }^{\circledR}$ on diet at $9 \mathrm{mg} / \mathrm{kg}$ bw per day), the induced colitis by the oral administration of dextran sodium sulfate had statistically significant histological parameters less severe, including the inflammatory infiltrate (Vrublova et al., 2010). Calves with enteritis induced by Crytosporidium spp. and treated with the same alkaloids had an amelioration in the clinical conditions of the treated group (Mendonça et al., 2016). The soft tissue results of the current experiment are in accordance with these descriptions except for the ileum were the cell counting raised. It could be explaining by the normal presence of lymphoid tissue and their modulated activity by the alkaloids used (Lenfeld et al., 1981; Newton et al., 2002; Jankowski et al., 2009).

\section{Conclusions}

In this trial, diverse gastro intestinal microscopic lesions induced by SARA in feedlot cattle treated with isoquinolone alkaloids ( $\mathrm{SG}, \mathrm{HC}$ and PRO) expressed ameliorations and worsening's. Ameliorating effects of the alkaloids were better demonstrated in tissues with reduced or no corneal layer in the mucosa and in the absence of a lipopolysaccharides rich acidic 
environment reinforcing the notion of the topic action, the dependence of the media $\mathrm{pH}$ and the time of exposure modulating the pharmacological mechanisms of these alkaloids. The observed cytolytic (oncolysis) effect in cells under low $\mathrm{pH}$, worsening the osmotic status, should be considered.

\section{Acknowledgements}

The authors acknowledge Phytobiotics (Eltville, Germany) for the financial support to this research, UNICENTRO (Guarapuava, Brazil) for the use of its facilities, and CAPES (Brazil) for the $\mathrm{PhD}$ scholarship to the corresponding author.

\section{References}

Armstrong, C. M. (2003). The Na K pump, $\mathrm{Cl}$ ion, and osmotic stabilization of cells. PNAS, 100(10), 62576262. doi: 10.1073/pnas.0931278100

Belote, B. L., Tujimoto-Silva, A., Hummeelggen, P. H., Sanches, A. W. D., Wammes, J. C. S., Hayashi, R. M., \& Santin, E. (2018). Histological parameters to evaluate intestinal health on broilers challenged with Eimeria and Clostridium perfringens with or without enramycin as growth promoter. Poultry Science, 97(7), 1-8. doi: 10.3382/ps/pey064.

Costa, V. A. C., Detmann, E., Valadares, S. C., Fo., Paulino, M. F., Henriques, L. T., \& Mantovani, H. C. (2008). Degradação in vitro da fibra em detergente neutro de forragem tropical de baixa qualidade em função de suplementação com proteína e/ou carboidratos. Revista Brasileira de Zootecnia, 37(3), 494-503. doi: 10.1590/S1516-35982008000300015.

Dirksen, G. U., Liebich, H. G., \& Mayer, E. (1985). Adaptive changes of the ruminal mucosa and their functional and clinical significance. The Bovine Practitioner, 20, 116-120.

Estrada-Ângulo, A., Aguilar-Hernandez, A., OsunaPerez, M., Nunez-Benitez, V. H., Castro-Perez, B. I., \& Silva-Hidalgo, G. (2016). Influence of quaternary benzophenantridine and protopine alkaloids on growth performance, dietary energy, carcass traits, visceral mass, and rumen health in finishing ewes under conditions of severe temperature-humidity index. Asian-Australasian Journal of Animal Sciences, 29(5), 652-658. doi: 10.5713/ajas.15.0300.
Gonin, S., Deschenes, G., Roger, F., Bens, M., Martin, P.Y., Carpenter, JL., Feraille, E. (2001). Cyclic AMP increases cell surface expression of functional $\mathrm{Na}$, $\mathrm{K}$-ATPase units in mammalian cortical collecting duct principal cells. Molecular Biology of the Cell, 12(2), 255-264. doi: 10.1091/mbc.12.2.

Hernández, J., Benedito, J. L., Abuelo, A., \& Castillo, C. (2014). Ruminal acidosis in feedlot: from aetiology to prevention. The Scientific World Journal, (2014), 1-8. doi: 10.1155/2014/702572.

Herrera-Mata, H., Rosas-Romero, A., \& Crescente, O. (2002). Biological activity of sanguinaria (Justicia secunda) extracts. Pharmaceutical Biology, 40(3), 206-212. doi: 10.1076/phbi.40.3.206.5826

Hu, Z.B., Xu, Y., Feng, S.C., \& Guang-Jin, F. (1979). Studies on the active components from fruits of Macleaya cordata (Willd) R. Br [J]. Acta Pharmaceutica Sinica, 14(9), 535-539.

Jankowski, J., Zdunczyk, Z., Juskiewicz, J., Koztoski, K., Lecewicz, A., \& Jeroch, H. (2009). Gastrointestinal tract and metabolic response of broilers to diets with the Macleaya cordata alkaloid extract. Archiv für Geflugelkunde, 73(2), 95-101.

Johnson, C. C., Jonhson, G., \& Poe, C. F. (1952). Toxicity of alkaloid to certain bacteria. II. Berberine, physostigmine and sanguinarine. Acta Pharmacologica et Toxicologica, 8(1), 71-78. doi: 10.1111/j.1600-0773.1952.tb02885.x

Kosina, P., Gregorova, J., Gru, J., Vacek, J., Kolar, M., Voguel, M., \& Ulrichova, J. (2010). Phytochemical and antimicrobial characterization of Macleaya cordata herb. Fitoterapia, 81(8), 1006-1012. doi: 10.1016/j.fitote.2010.06.020

Kraieski, A. L., Hayashi, R. M., Sanches, A., Almeida, G. C., \& Santin, E. (2017) Effect of aflatoxin experimental ingestion and Eimeira vaccine challenges on intestinal histopathology and immune cellular dynamic of broilers: applying an Intestinal Health Index. Poultry Science, 96(5), 1078-1087. doi: $10.3382 / \mathrm{ps} /$ pew397

Lauf, P. K., Heinyd, J., Meller, J., Lepera, M. A., Koikovd, L., Alter, G.M., Brown, TL., \& Adragna, N.C.(2013). Canonical Bcl-2 motifs of the $\mathrm{Na}+\mathrm{K}+$ pump revealed by the $\mathrm{BH} 3$ mimetic chelerythrine: early signal transducers of apoptosis? Cellular Physiological Biochemistry, 31(2-3), 257-276. doi: $10.1159 / 000343366$.

Lenfeld, J., Kroutil, M., Marsalek, E., Slavik, J., Preinningger, V., \& Simanek, V. (1981). Anti-inflammatory activity of quaternary 
benzophenanthridine alkaloids from Chelidonium majus. Planta Medica, 43(10), 161-165. doi: 10.1055/s-2007-971493.

Mahody, G. B., Pendland, S. L., Stoia, A., \& Chadwhick, L. R. (2003). In vitro susceptibility of Helicobacter pylori to isoquinoline alkaloids from Sanguinaria canadensis and Hudrastis canadensis. Phytotherapic Reserach, 17(3), 217-221. doi: 10.1002/ptr.1108.

Mendonça, F. L. M., Silva, R. J., Andrade, J. P., Ferreira, L. D., Rogge, H. I., Ferreira, L. C. A., \& Facury, E. J., Fo . (2016). Assessment of dietary isoquinoline alkaloids in the prevention of cryptosporidiosis in newborn calves. Proceedings of the Congress of the World Association for Buiatrics, World Buiatrics Congress, Dublin, Irlanda, 29.

Millen, D. D., \& Arrigoni, M. D. B. (2013). Drivers of change in animal protein production systems: Changes from "traditional" to "modern" beef cattle production systems in Brazil. Animal Frontiers, 3(3), 56-60. doi: 10.2527/af.2013-0025

Morgante, M., Stelletta, C., Berzaghi, P., Gianesella, M., \& Andrighetto, I. (2007). Subacute rumen acidosis in lactating cows: An investigation in intensive Italian dairy herds. Journal of Animal Physiology and Animal Nutrition, 91(5-6), 226-234. doi: 10.1111/j.1439-0396.2007.00696.x

Newton, S. M., Lau, C., Gurcha, S. S., Besra, G. S., \& Wright, C. W. (2002). The evaluation of fortythree plant species for in vitro anti-mycobacterial activities: isolation of active constituents from Psoralea corylifolia and Sanguinaria canadensis. Journal of Ethnopharmacology, 79(1), 57-67. doi: 10.1016/s0378-8741(01)00350-6

Oetzel, G. R. (2000). Clinical aspects of ruminal acidosis in dairy cattle. Proceedings of the RD Annual Convention of the American Association of Bovine Practitioners, Rapid City, South Dakota USA, 33.

Pitts, B. J. R., \& Meyerson, L. (1981). Inhibition of $\mathrm{Na}, \mathrm{K}$-ATPase activity and ouabain binding by sanguinarine. Drug Development Research, 1(1), 4349. doi: 10.1002/ddr.430010105

Plaizier, J. C., Khafipour, E., Li, S., Gozho, G. N., \& Krause, D. O. (2012). Subacute ruminal acidosis (SARA), endotoxins and health consequences. Animal Feed Science and Technology, 72(1-2), 9-21. doi: 10.1016/j.anifeedsci.2011.12.004
Sato, S. (2015). Subacute ruminal acidosis (SARA) challenge, ruminal condition and cellular immunity in cattle. Japanese Journal of Veterinary Research, 63(1), 25-36. doi: 10.14943/jjvr.63.suppl.s25

Slaninova, I., Taborska, E., Bochorakova, H., \& Slanina, J. (2001). Interaction of benzo[c]phenanthridine and protoberberine alkaloids with animal and yeast cells. Cellular Biology Toxicolology, 17(1), 51-63. doi: 10.1023/a:1010907231602.

Straub, K. D., \& Carver, P. (1975). Sanguinarine, inhibitor of NA-K dependent ATP'ASE. Biochemical and Biophysical Research Communications, 62(4), 913922. doi: 10.1016/0006-291X(75)90410-6

Tajik, J., Nadalian, M. G., Raoofi, A., Mohammad, G. R. I., \& Bahonar, A. R. (2009). Prevalence of subacute ruminal acidosis in some dairy herds of Khorasan Razavi province, northeast of Iran. Iranian Journal of Veterinary Research, 10(26), 28-32.

Vrublova, E., Vostalova, J., Ehrmann, J., Palikova, I., Vrbkova, J., Vacek, J., Simanek, V. (2010). The phytogenic feed additive Sangrovit modulates dextran sulfate sodium-induced colitis in rats. Veterinarni Medicina, 55(12), 610-618. doi: 10.17221/2945-VETMED.

Walker, C. (1990). Effect of sanguinarine and sanguinarine extract on the microbiota associated with the oral activity. Journal o. Canine. Dentistry. Association, 56(7), 13-17

Windisch, W., Schedle, K., Plitzner, C., \& Kroismayr, A. (2008). Use of phytogenic products as feed additives for swine and poultry. Journal of Animal Science, 86(14), 140-148. doi: 10.2527/jas.2007-0459

Xu-Biao, L., Chen, B., \& Yao, S. Z. (2006). Rapid determination of protopine, allocryptopine, sanguinarine and chelerythrine in fruits of Macleaya cordata by microwave-assisted solvent extraction and HPLC-ESI/MS [J]. Phytochemical Analysis, 17(6), 431-438. doi: 10.1002/pca.945

Zdarilova, A., Vostálová, J., Vrublova, E., \& Klejdus, B. (2008). Natural feed additive of Macleaya cordata: Safety assessment in rats a 90-day feeding experiment. Food and Chemical Toxicology, 46(12), 3721-3726. doi: 10.1016/j.fct.2008.09.054 
